\title{
Babies with microcephaly in Brazil are struggling to access care
}

\author{
Cláudia Collucci
}

São Paulo

One year after the Brazilian Ministry of Health declared a public health emergency because of the large rise in the number of children born with microcephaly, those children are experiencing difficulties in accessing care.

The first of these children are now a year old, but most cannot crawl, walk, sit unaided, or hold objects. Many have severe visual and hearing deficiencies and malformations in the legs and arms. Most take painkillers to control irritation and repeated crying, and receive treatment for seizures.

By the end of October Brazil had 2106 confirmed cases of congenital Zika virus syndrome. Another 3091 cases remain under investigation. ${ }^{1}$ Around $80 \%$ of cases are concentrated in the north east of the country. The BMJ spoke to families of babies with the syndrome in the two north eastern states of Paraiba and Pernambuco and to the clinicians treating them. Together these two states are home to about 600 affected children, the majority born into low income families who reported difficulties in accessing medicine and investigations in the public health system, Sistema Único de Saúde (SUS), and in transportation to specialist health services.

Microcephaly is not the only malformation caused by the Zika virus. Liana Ventura, an ophthalmologist from the Altino Ventura Foundation in Recife, Pernambuco, said that $40 \%$ of children with suspected microcephaly had ocular lesions, especially in the retina and optic nerve, and $6 \%$ had auditory deficits. She said that the lack of access to treatment early on may further compromise neuromotor development.

Jeime Leal, a physiotherapist in Campina Grande, Paraiba, said that the response to treatment depended on the severity of lesions caused by the Zika infection and how soon physical therapies - such as physiotherapy, treatment for swallowing, and language disorders - were started. "The sooner the better," she said. "The response to treatment is slow because the brain damage is severe. But we have cases of children that interact with their eyes, and one of them, after a year, started to take their first steps."

Adriana Melo, a doctor from Campina Grande, Paraiba, said that she had recently seen a baby who, at eight months, could not swallow and had to be tube fed. "None of the babies that started to be stimulated early had this difficulty," she said.
In addition to microcephaly, one year old Pérola has impaired hearing and vision, including sensitivity to light and long sightedness. She also has reflux and, as well as taking medication, has speech therapy to improve swallowing. Pérola's mother, Marcione Gomes da Rocha, 29, from Betania, takes her $400 \mathrm{~km}$ to Recife, the state capital of Pernambuco, every week for physiotherapy, speech therapy, and other medical consultations. Often, the municipality does not provide transportation, and Pérola misses therapy sessions and doctors' appointments. This is a scenario that many families who have children with congenital Zika virus syndrome can relate to.

The Ministry of Health said that it offered financial support to transport babies with microcephaly for treatment in major centres. It said that it was expanding its network of medical services to reduce the gaps in care services in the north east. Access to drugs through SUS is another problem, caused by scarcity and distribution problems. Some of the most expensive medicines, such as the epileptic drug Sabril, are not supplied by the public system. Josikelly da Silva, 32, from Recife, is mother to Lurranda, a one year old girl. She said that she spent almost all of her social benefit ( $\$ 270$ ( $£ 220 ; € 250)$ a month) on anticonvulsants, tranquilisers, reflux drugs, and special milk. Lurranda was born with microcephaly and, at four months, had severe seizures that left her more debilitated. Her mother also reported delays in accessing investigations, in particular electroencephalography. "I've been waiting for more than four months. It's always broken," she said.

Luciana Albuquerque, executive secretary of health surveillance in Pernambuco, said that the lack of some drugs in the public system was due to problems with the distributor that were expected to be resolved by the end of this month. However, she acknowledged that some drugs, including Sabril, were not currently supplied through SUS and that they were looking at how to redress this. She also confirmed that demand for electroencephalography was currently exceeding the capacity available and that this too would be rectified by the end of the month.

Federal Government of Brazil. Ministry of Health. Epidemiological situation. http:// combateaedes.saude.gov.br/en/epidemiological-situation.

Published by the BMJ Publishing Group Limited. For permission to use (where not already granted under a licence) please go to http://group.bmj.com/group/rights-licensing/ permissions 